\section{Report on the Annual Meeting of the \\ European Association of Archaeologists (Barcelona, 5-8 September 2018)}

\author{
Margarita Díaz-Andreu \\ Sandra Montón \\ Raquel Piqué
}

The $24^{\text {th }}$ Annual Meeting of the European Association of Archaeologists ${ }^{1}$ was held in Barcelona on 5-8 September this year. This article is a report on that meeting, although prior to describing the meeting itself, we would like to briefly explain about the origin and nature of the association. The objectives of the EAA are to promote archaeological research and the exchange of information; to foster the management and interpretation of European archaeological heritage; to incite respect for the appropriate ethical and scientific standards; to bolster the interests of the archaeological collective in Europe; and to foster cooperation with other organisations with similar objectives. ${ }^{2}$ The EAA was originally conceived with a much humbler idea: to publish a European-wide archaeology journal. It was not long after that this plan became somewhat more ambitious and an institution was established to serve as a basis for the publication (Kristiansen 2004: 3). The official foundation of the EAA took place in 1994 in Ljubljana (Slovenia), almost 25 years ago (Novakovic 2013). Its first congress was held one year later in Santiago de Compostela (20-24 September 1995). Since then the EAA has met annually in different European countries and venues. Its journal, the European Journal of Archaeology, just published its $20^{\text {th }}$ edition. ${ }^{3}$

In 2014, the University of Barcelona (UB), with the support of other Catalan institutions, and the indispensable assistance of the Barcelona Tourism Convention Bureau (which at the time was interested in promoting Barcelona as a congress destination, RB 2013), drew up a proposal to organise the 2018 Annual Meeting. The candidature, which was presented along with letters of support from the Catalan Regional Government, Barcelona City Council and the different universities and main research centres of Catalonia, was accepted. The green light to go ahead with the project was announced at the Annual Meeting of Members (AMBM, infra) 12 September 2015 in Istanbul in the presence of Margarita Díaz-Andreu (ICREA, UB), Sandra Montón Subías (ICREA, UPF)

1. <https://www.e-a-a.org/>.

2. <www.e-a-a.org/AboutEAA>.

3. The European Journal of Archaeology was preceded by the Journal of European Archaeology, of which five editions were published. The name was changed in 1994 to better reflect the journal's global, rather than a purely European, scope.

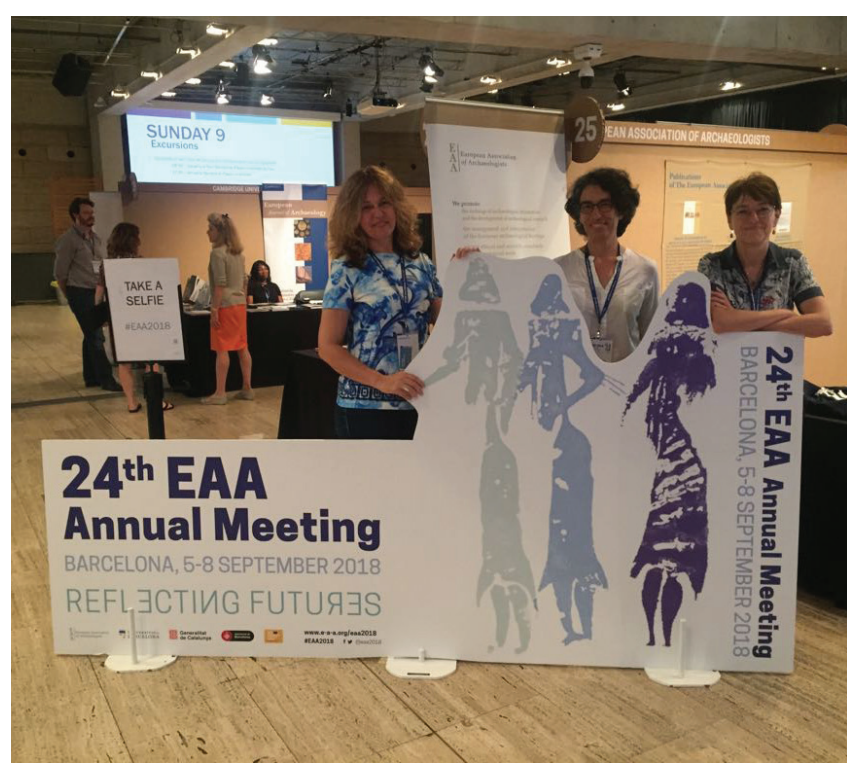

Figure 1.- Local Organising Committee of the EAA

Barcelona 2018. From left to right Sandra Montón

(ICREA, UPF), Margarita Díaz-Andreu (ICREA, UB) and Raquel Piqué (UAB).

and Raquel Piqué (UAB), who would subsequently embody the Local Organising Committee (Figure 1).

A congress of this type requires a huge organisational effort, effort that started especially in September 2016, following the EAA Annual Meeting in Vilnius. We were convinced that the organisation of an event of this calibre would be unachievable for a university administration without a specialised staff or the capacity of reaction essential to this type of undertaking. We therefore enlisted the support of professionals of the sector such as the firm Kultura, idees $i$ estratègies per al patrimoni, who suggested we also count on Manners, a company which specialises in the organisation of such events. As a result, in spring 2017, agreements were signed between the EAA and the companies as well as the UB.

In parallel, a new organisational model was introduced in 2018 for the Annual Meeting which to a large extent followed the example of the large congresses organised by the Society for American Archaeology (SAA). The EAA central office in Prague was also to become much more involved in the organisation of the annual meetings. The objective was to offer continuity to the experience, stability in the organisational design, and a control over the financial aspects of the event. The central office now attends to registration, membership applications and proposals for sessions and papers. It also maintains and updates the EAA website. All in all, therefore, many actors were involved in the organisation of the EAA in Barcelona. These were the University of Barcelona as the official organiser with the EAA backed by the Autonomous University of Barcelona, the Pompeu Fabra University, ICREA and Manners and Kultura, ${ }^{4}$ the last two linked under a temporary consortium (UTE). ${ }^{5}$ The organisation was also assessed

4. <http://manners.cat, http://www.kultura.cat/>.

5. Unió Temporal d'Empreses 
by an Advisory Board consisting of almost 30 representatives from all sectors of Catalan archaeology: administration, research centres, museums, private sector and universities. ${ }^{6}$

The scientific content of the congress became clear very early on. Each EAA Annual Meeting chooses a series of specific subjects aimed at focusing the discussions. This idea emerged as a way of ensuring that the debates were not only going to be exclusively limited to archaeological interpretation, as was the norm until the 1980s. The idea was that they encompassed other subjects of current interest including commercial archaeology (which was fast gaining ground at that time and currently occupies more than half of the professionals of the sector), archaeological management by administrations and private companies and, finally, so-called public archaeology. Thus, the major topics for discussion of each Annual Meeting represent all those interests as well as a wide range of themes more specific to the host country or to a characteristic event corresponding to the date of the event. Among the wide range of themes chosen for the EAA Barcelona 2018 were a first on "theory and method" and a second on "cultural material, bodies and landscapes". The third and fourth, specific to Barcelona, were "marine landscapes" and "archaeology and the future of cities and urban landscapes". The fifth was chosen in keeping with the European Year of Cultural Heritage. Finally, the sixth was aimed at ending the absence of museum-related subjects in the annual EAA meetings and included this proposal in the debates on the challenges facing heritage in the $21^{\text {st }}$ century. The initial list was proposed by the Barcelona team comprising the Local Organising Committee and the temporary consortium. Having obtained the accord of the EAA management, it was finalised with the agreement of the Scientific Committee at the 27 November 2017 meeting. The Barcelona organising team and Kultura also came up with the slogan "Reflecting Futures" and the logo with the three female figures from the Roca dels Moros rock art shelter of Cogul (Figure 2). Moreover, the dominant blue hues chosen to depict the congress meant to evoke Barcelona's Mediterranean character.

The period for proposing sessions for Barcelona opened shortly after the Maastricht Annual Meeting and closed on 13 November 2017. This was a time of uncertainty for the EAA, until reception of the total number of proposals. The health of an association depends in part on the success of its calls. We wondered if the tragedy of the terrorist attack of 17 August, the unstable political situation in Catalonia and the distressing images of 1 October reproduced on TV screens all over the world would put people off to attending the event in Barcelona. Yet our worries were unfounded as the number of proposals for sessions exceeded all expectations.

After evaluating all the proposals, the Scientific Committee approved a total of 272. This was followed by a period to present contributions to each of the sessions (15 December to 19 February). More than

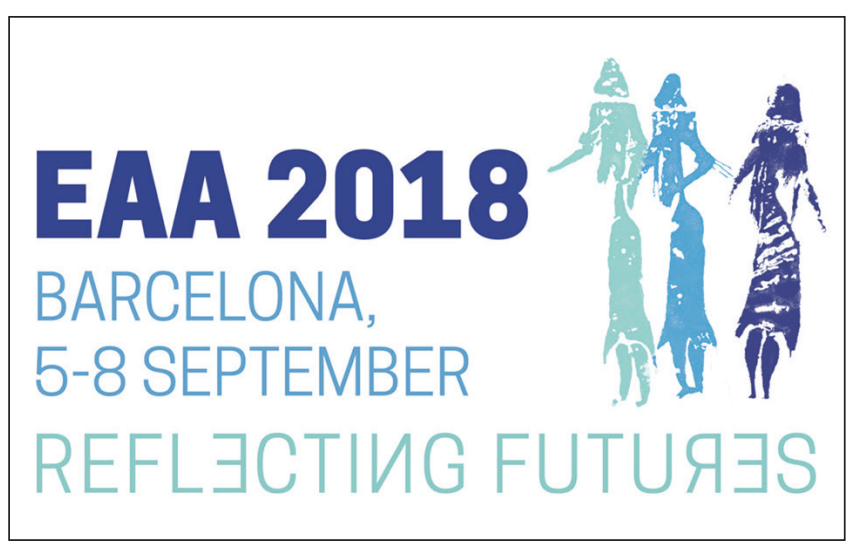

Figure 2.- Logo with the three female figures of the rock art shelter of la Roca dels Moros at Cogul.

3,100 proposals were submitted to be evaluated by the organisers of each session. Once the approximate number of attendees was known, the Barcelona team "stepped on the accelerator" to organise what was turning out to be the best-ever EAA Annual Meeting.

The assistance of volunteers ${ }^{7}$ was, without a doubt, as in the case of previous meetings, crucial to the success of the event. These graduate and especially postgraduate students, as in other large congresses such as the TAG (Theoretical Archaeology Group), WAC (World Archaeological Congress) and SAA (Society for American Archaeology), were vital to attend to the numerous small and large tasks involved in the dayto-day running of a congress. Volunteers accompanied excursions, minded the information desk, registered the participants and placed the indicatory signs. Their presence in the halls ensured the smooth running of the session and solved a number of problems.

The period to sign up as a volunteer was from 23 January to 15 March. More than 400 students applied for a total of 50 positions (subsequently increased to $60)$. We were fortunate to be able to count on the expertise of Laura Coltofean and Amilcar Vargas to directly organise the volunteers.

The vast proportions of the Barcelona EAA event meant that the volunteers had to work hard, although in compensation they also received benefits that will no doubt make a difference to their academic careers. We believe the expression "win-win" best defines the relationship between the volunteers and the EAA. Despite their high cost for the organisers (for example, all the registration fees and food and board for those from outside the city are automatically covered), these young volunteers represent the future of our profession and, at the same time, they establish a link with the organisation that can have a positive influence on its continuity. For many students, this is the only way to be able to take part in such an important international congress while, at the same time, offer a paper or a poster, a fact that will, as noted above, contribute positively to their curricula. 
The Barcelona Annual Meeting got under way officially on 5 September 2018, although the warm-up had begun two days earlier. It was then that all the volunteers arrived and attended a training session of several hours. This culminated in a get-together with cocktails, where international friendships immediately began to be forged. While some of the volunteers were given the day off on Tuesday (to compensate for the long hours they would have to put in on the following days), others accompanied visitors on organised excursions. ${ }^{8}$ The excursions had been initiated at the weekend with a trip to Menorca and continued on Tuesday with visits to Ullastret and Empúries, Tárraco, Vilars d'Arbeca and La Seu Vella, and Serinyà and La Draga. The following day there were also half-day outings to La Roca dels Moros at Cogul, the Mines of Gavà, the Iberian settlement of Calafell, and the Gothic Quarter in Barcelona. On the Sunday after the congress, excursions were organised to the Iberian settlement and Spanish Civil War airraid defences of El Turó de la Rovira, the L'Abric Romaní in Capellades and the Badalona Museum.

Other activities took place in Barcelona in parallel to the excursions on 5 September. The EAA president (Felipe Criado), the chair of the Local Organising Committee (Margarita Díaz-Andreu), the president of the Association of Catalan Archaeologists in representation of Catalonian archaeology (Isidre Pastor), and a long-standing member of the EAA (Pedrag Novakovic) began the day with a press conference followed by a president's lunch. The latter took place in company of about 30 representatives of professional groups from the European area, large associations such as ICOMOS and ICOM, and major actors from the private sector. Special guests were also invited, including the president of the SAA, Susan Chandler, and her executive director, Toby Brimsek, and the president of WAC, Koji Mizoguchi. The subject at the table was "What new abilities do we need in archaeology?" which led to a discussion concerning the lack of training of young people entering the profession in terms of soft skills. These skills include the ability to communicate, deal with ethical questions, basic entrepreneurial knowledge, etc. An important question advanced was if this could be improved, for example, by training organised by the EAA. The minutes of this meeting has been published in the last (58) online, access-free edition of The European Archaeologist, ${ }^{9}$ the EAA's newsletter.

For many of the congress delegates, Wednesday 5 September began with registration and collection of congress material. The registration desk was scheduled to open at noon, but this was advanced to 9 am to avoid queuing and to allow the delegates to enjoy the European Archaeology Fair $^{10}$ that had just opened. This fair included stands from various universities (UB, UAB, Durham, Groningen), research centres (INCIPIT, IEMA), administrations (Barcelona City Council, the Catalan Regional Government, Axencia

8. <https://www.e-a-a.org/EAA2018/excursions>.

9. <https://www.e-a-a.org/EAA/Publications/TEA/EAA/Navigation_Publications/TEA_home.aspx>

10. <https://www.e-a-a.org/EAA2018/fair>.
Galega de Innovación, Menorca, the Canary Islands ${ }^{11}$ ); associations such as the Marie Curie Alumni; publishing houses (Archaeolingua, Boccard, BAR, Brepols, Oxbow, OUP, CSIC, CUP, Taylor \& Francis); projects such as ArchAIDE; and archaeological service companies (e.g., Beta Analytic and Sensors \& Software). Other delegates took the opportunity to visit certain museums that were offering free admission during the congress, an initiative that was well received. The Museum of Archaeology of Catalonia, for example, reported that Tuesday and Wednesday were their busiest days, with a total of 453 visits (Joan Muñoz, pers. com. 12 Sept). Moreover, midday Wednesday saw the meeting of delegates belonging to about 17 communities, committees and task forces ${ }^{12}$ forming part of the EAA. These have emerged from the interests of different groups of members covering a wide range of aspects within archaeology, including climate change, gender, illicit trade of cultural material, wild plants, mediaeval Europe and public archaeology.

The main event in the afternoon was the opening ceremony ${ }^{13}$ held between 5 and $7 \mathrm{pm}$ in the incomparable setting of the church of Santa Maria del Mar. The choice of this venue stems from the generosity of the parish authorities and the Ateneu Universitari Sant Pacià (Figure 3). The church was teeming to the brim with 1,242 delegates that had reserved in advance. The master of ceremonies (Eddy Vidal) hosted the ceremony magnificently, introducing the different welcome speeches (Margarita Díaz-Andreu representing the Local Organising Committee; David Abadías from the Antoni Gaudí University; Jaume Asens, deputy mayor of Barcelona City Council; Albert Cirera Hernández, Vice Chancellor for Entrepreneurship, Transference and Innovation at the UB; Laura Borràs, Minister of Culture for the Catalan Regional Government; and Felipe Criado, president of the EAA). The EAA president also oversaw the presentation of awards (Archaeological Heritage and the best paper submitted by a student). To conclude the event, brief inaugural lectures were read by Francisco Gràcia (UB) and Sonia Gutiérrez (University of Alicante). Musical accompaniment for the ceremony was provided by the guitars of Alícia Grillo and Sandra Monfort. After the reception, the delegates strolled to the Born Centre for Culture and Memory accompanied by music played by shawms where they were offered a glass of cava while the Castellers of San Cugat raised several magnificent human towers $(a 4, a 4$ of 6 , a 3 of 7 , and a 4 of 5) including two congress delegates!

The academic component of the congress programme was held between Thursday 6 and Saturday 8 September. The different parallel sessions were structured around 15 minute papers and discussion time, with a required minimum of 5 and a maximum of 22 papers. They were organised into two-hour blocks separated by half-hour breaks, twice a day, during which the delegates were offered coffee. A session could extend to a maximum of four blocks, i.e. eight hours. The 


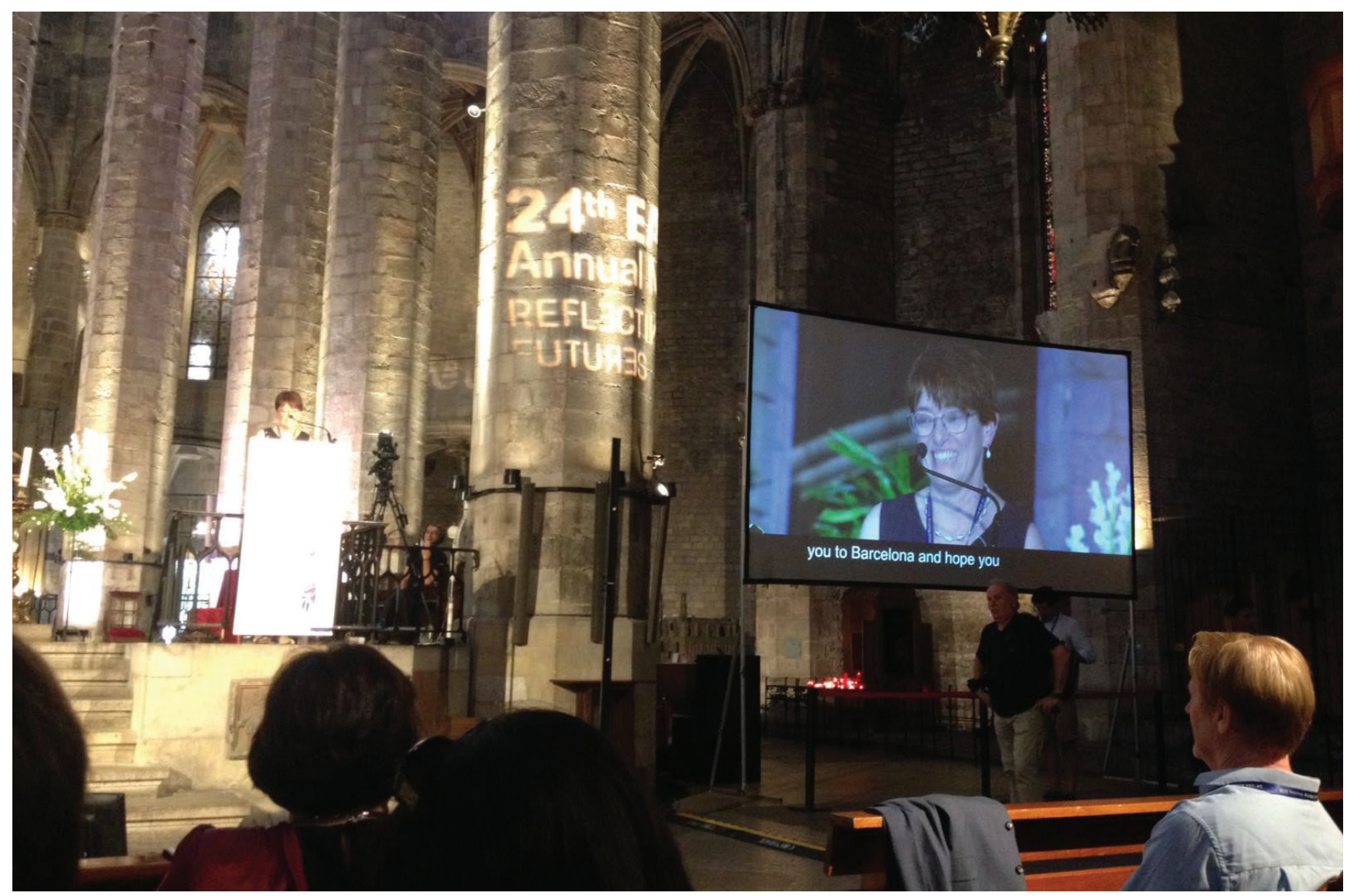

Figure 3.- Inaugural ceremony held at Santa Maria del Mar on 5 September 2018.

subject matter of the 260 sessions and almost 3,000 presentations (174 as posters) was extremely varied (Figure 4). This is to be expected during a period of theoretical, although perhaps not methodological, stasis currently experienced in archaeology.

Our preliminary analysis, based on a survey of keywords, points to the tendency to resort to chronology as the delimiting element, with a greater number of presentations on Prehistory, followed by the Middle Ages and historical archaeology, with a lesser presence of classical archaeology. There also appears to more emphasis afforded to scientific methods of all types and on heritage (despite the fact that the Barcelona meeting coincided with other congresses of similar subject matter). Other important trends are those of gender archaeology, marine archaeology, archaeological landscapes, and virtual and digital archaeology. A comment we heard several times, and one that coincided with our perception, was that although the time devoted to discussion was limited, there was a high degree of participation by those attending the sessions, therefore allowing an exchange of opinions that made a positive contribution to advancing knowledge on the subject in question.

All the sessions were transnational; in other words, no session was devoted exclusively to one country or European region. This is no coincidence as the EAA considers this a particularly important criterion and achieves it by requiring a session to be organised by at least two institutions from different European countries. If, despite everything, a session is limited in geographical scope, the Scientific Committee only yields if it is transversal in some way. If this requirement was not met, the EAA Annual Meeting would fail to fulfil one of its fundamental objectives: the circulation of knowledge between archaeologists in diverse parts of Europe and the world, and the creation of networks of all types to provide continuity to those connections. This was precisely one of the reasons for the congress motto to be "Reflecting Futures"!

The sessions were held between 8.30 am and 6.30 pm. Subsequently, on both Thursday and Saturday, keynote lectures ${ }^{14}$ were delivered (six on Thursday and five on Saturday). The invited speakers were chosen along various criteria including gender (to achieve the parity that is so crucial in setting a benchmark for future women professionals of archaeology) geography, language and theme. The only lecture programmed outside the normal schedule, due to questions of agenda, was that of José Labastida, director of the Department of Scientific Management of the European Research Council (ERC), who described the actions taken by his agency to promote research. That afternoon we were offered lectures by Eszter Bánffy (Roman-Germanic Commission of Frankfurt) on the Northern Boundary of Neolithic 'Clayscapes' and the

14. <https://www.e-a-a.org/EAA2018/keynotes>. 


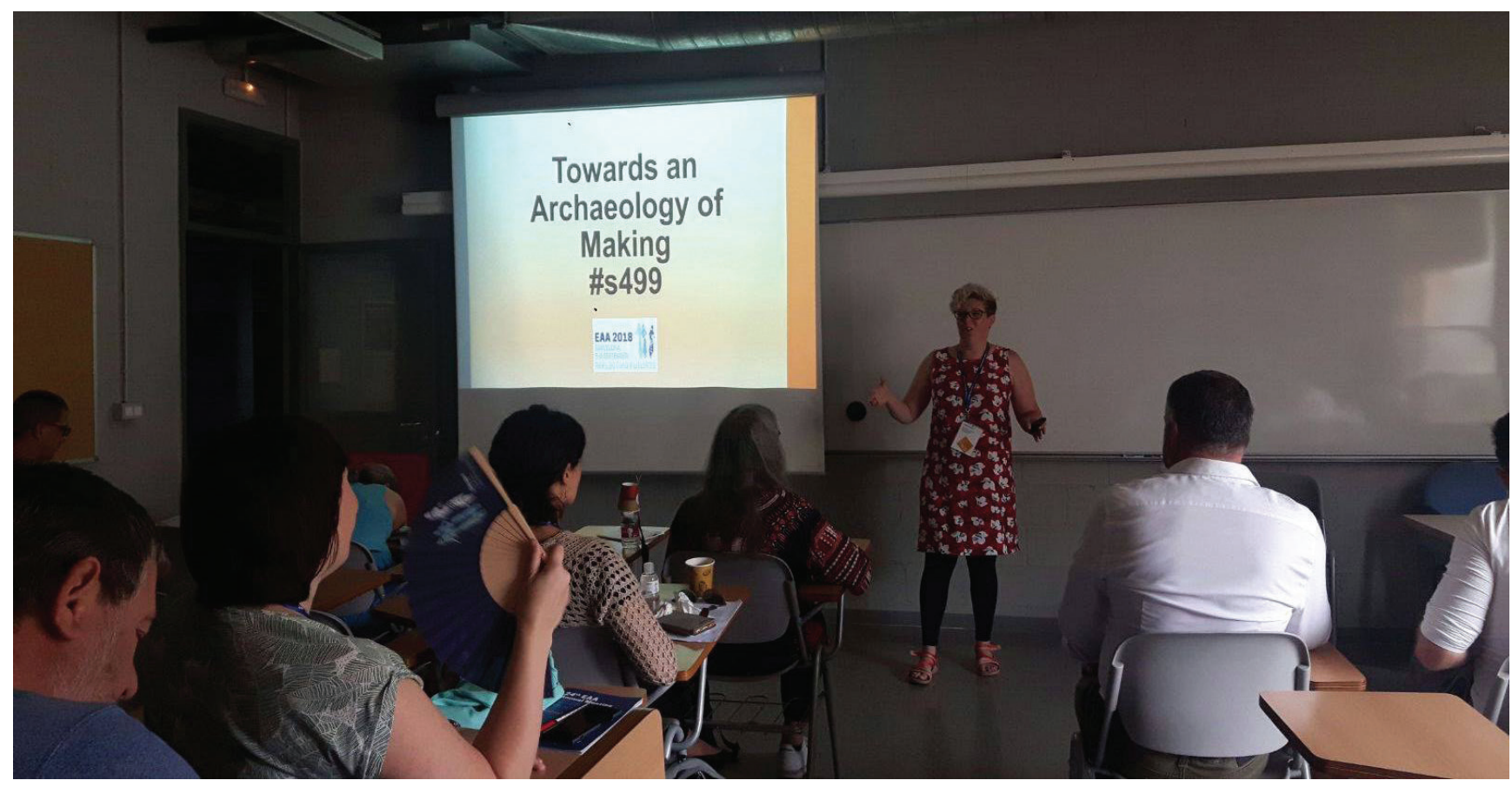

Figure 4.- "Towards an archaeology of making" session on 8 September 2018.

Roots of the Bandkeramik; Diane Gifford-Gonzalez (ex-president of the SAA) on the need for archaeology to become involved in the challenges posed by climate change; Brit Solli (Museum of Cultural History, University of Oslo) on the archaeology of the Anthropocene; Alfredo González-Ruibal (INCIPIT) on conflict archaeology; and George Abungu (ex-director general of the National Museums of Kenya) on archaeology and heritage in Africa and the need to decolonise the archaeological narrative. In parallel, the Splendour of Catalan Mediaeval Castles exhibition was inaugurated at the Museum of Archaeology of Catalonia, where two sessions had been organised to accommodate the interested delegates.

The Saturday keynote lectures were given by Sophia Labadi (University of Kent and UNESCO consultant) on the subject of the relevance of World Heritage (Figure 5); Soultana Maria Valamoti (University of Thessaloniki) on archaeobotany and the modern narratives regarding food consumption; Paloma GonzálezMarcén (UAB-CEPAP) on different projects related to the transmission of archaeological knowledge to the general public based on the identification of the main social challenges of the $21^{\text {st }}$ century; Jean-Paul Demoule (emeritus professor at the Sorbonne) on his view of the European Union and the preservation of archaeological heritage; and, finally, Predrag Novaković (University of Ljubljana) on the past and present of European social archaeological landscapes.

The Arqueologia al Carrer (Archaeology in the Street $)^{15}$ programme for the residents of Barcelona was organised in parallel to the academic agenda. This was made possible mainly due to funding from the UB and a considerable effort from Margarita Díaz-Andreu,

15. <https://www.e-a-a.org/eaa2018/PublicEvents>. supported by Laura Coltofean, and later, the key intervention of Isidre Pastor. This included a walk through Barcelona organised by GAPP ${ }^{16}$ (Public Archaeology and Heritage Group); open visits of the Antoni Tarrés ornamental pottery factory archaeological site ${ }^{17}$ at the UB Department of Geography and History hosted by archaeology degree students under the direction of Josep M. Gurt; two archaeo-experimentation workshops organised respectively by the Museum of Archaeology of Catalonia represented by Antoni Palomo ${ }^{18}$ (Figure 6) and KuanUm ${ }^{19}$ and historical re-enactments by the Project Phoenix, ${ }^{20}$ Ibercalafell $^{21}$ and Barcino Oriens ${ }^{22}$ groups. Other activities in parallel to the meeting were a cycle of archaeological films organised at the Filmoteca de Catalunya ${ }^{23}$ (part of which was postponed due to the floods of the early hours of Friday) and a series of talks held in the Barcelona municipal library network by Toni Fernàndez, Agnès Garcia Ventura, Joan F. Gibaja, Anna Gómez, Mireia López Bertran, Enric H. March, Miquel Molist, Carme Miró, Santiago Riera Mora and Jordi Ramos. In addition to the scientific and public archaeology programmes, other meetings took place during the three main days of the congress. The most noteworthy is the so-called Annual Membership Business Meeting (AMBM) held Friday corresponding to the Annual Meeting of the Association members. Despite being open to all members, attendance is

16. <http://gapp.cat/>

17. <http://www.ub.edu/grauarqueo/index.php/cat/moderna-contemporania/terrisseria-tarres $>$.

18. <http://www.mac.cat/>.

19. <Kuanum.blogspot.com/>.

20. <http://usuaris.tinet.cat/masefe/cat/legio01.html>.

21. <http://ibercalafell.org.es/>.

22. <http://www.barcinooriens.cat/>.

23. <http://www.filmoteca.cat/web/>. 

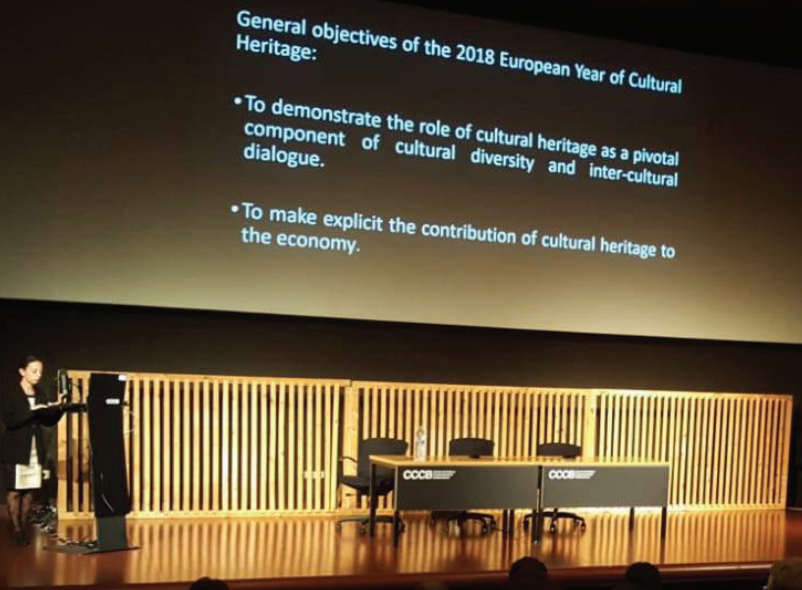

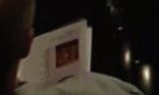

Figure 5.- Keynote lecture on the relevance of World Heritage by Sophia Labadi (University of Kent, UNESCO consultant).

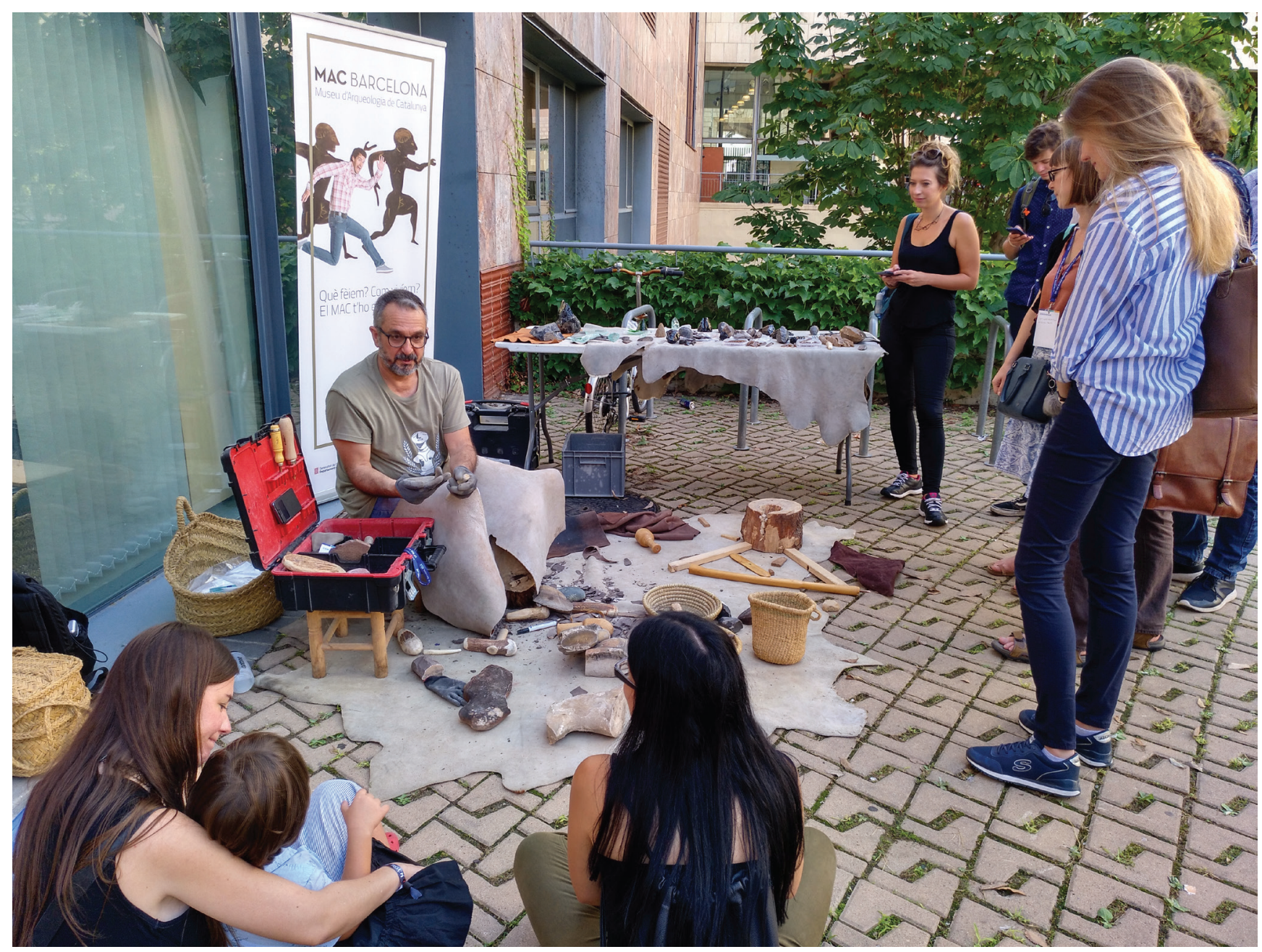

Figure 6.- Archaeo-experimentation workshop by Antoni Palomo (Archaeology Museum of Catalonia) at the Jardins de Victòria dels Àngels area. 
normally less than that desired by the EAA Executive Committee. The agenda ${ }^{24}$ included the association's accounts, membership fees, and the actions taken by the Oscar Montelius Foundation and other different communities, committees and task forces. The venue for the next EAA meeting in Berne, Switzerland, was also presented. Other smaller meetings were organised, including those with new EAA members (Thursday), corporate members (Friday) and the organisers of the next EAA annual meeting congresses (Saturday). Various EAA committees, including the Executive Committee and the Nominating Committee, also took advantage of the occasion to meet. Another activity was the committee's supervision of the counting of the votes cast during the congress (besides those cast electronically) to elect two members to the Executive Committee and a new member of the Nominations Committee. These results were then announced the next day during the AMBM.

Activities to unwind and relax were also scheduled during the meeting's three days. The long hours of work on Thursday were rewarded by a splendid —and for many, unforgettable - party at the Razzmattazz concert hall. The Catalan rumba group "Sabor de Gràcia" entertained the audience from both from the stage and the dance floor, and nobody wanted the party to end. Enjoying the party into the late hour meant that more than one delegate arrived bleary-eyed the next day or even missed the start of their session.

Friday corresponded to the MERC (Medieval European Research Community) party. Finally, the congress ended on Saturday with an excellent meal (the Annual Dinner) served at the Drassanes Reials (Royal Shipyards) of Barcelona and attended by about 400 archaeologists. After giving the closing speech, the EAA president presented bouquets to the main organisers of the event, including the authors of this report.

The impact of the EAA is growing and the association is aware that its presence on social media is essential for the large number of events organised within the framework of the congress to reach a wider audience. Twitter and Facebook accounts were therefore opened, the former with 814 followers and 369,000 views in the last month and the latter with 1,081 followers and approximately 10,000 visits since 4 September. The event was also covered by the media by more than 30 news items on TV, radio and in the printed press. Examples are the report on "The Archaeology of the Future" in the Ara newspaper on 4 September; the interview with Alfredo González Ruibal in La Vanguardia on the $7^{\text {th }}$ (also interviewed on TVE Catalonia for the weekend news on Saturday the $8^{\text {th }}$ ); the report on sexual harassment in $E l$ Periódico on the $9^{\text {th }}$ and the report on BTV on the "Archaeology in the Street" programme the same day. The EAA annual meeting has been further discussed at a later interview on BTV. ${ }^{25}$

It is difficult to assess the impact of this year's EAA meeting as so little time has elapsed since it was held. What is certain, nonetheless, is that it has placed the potential of Catalan archaeology firmly on the world stage, as the delegates included representatives from all the continents. At the same time, those of us from here were treated to an intensive course on what is being done in other countries.

There can be no doubt that the EAA Annual Meeting was a unique opportunity for meeting and establishing or re-establishing professional networks in Catalonia and Spain. It has been a long time since Catalan archaeologists specialising in any field of their discipline and/or working in any branch of the profession - commercial archaeology, university instruction, administration and museums - have had the opportunity to come together under one roof. It is also paramount to highlight the high participation of young people, who guarantee that the knowledge generated and transmitted in this meeting will reach the generations who, in just two decades, will be responsible for ensuring the continuing growth of archaeology. Finally, we were able once again to evidence, due to the success of the "Archaeology in the Street" programme and the attention of the media, the interest of the public in archaeology and hence the obligation of archaeologists to communicate and foster the social value of their discipline.

Margarita Díaz-Andreu ICREA, Universitat de Barcelona. m.diaz-andreu@ub.edu

Sandra Monton Subías ICREA, Universitat Pompeu Fabra sandra.monton@upf.edu

Raquel Piqué

Universitat Autònoma de Barcelona raquel.pique@uab.cat

\section{References}

Kristiansen, K. (2004). EAA beginnings, memories and retrospective reflections. The European Archaeologist [special issue: The European Archaeologist Anniversary Conference Issue 2004]: 3-5.

Novakovic, P. (2013). 'The EAA is Up and Running': Behind the Scenes of the Inaugural Meeting of the European Association of Archaeologists. In: S. Bergerbrant and S. Sabatini (eds). Counterpoint. Essays in Archaeology and Heritage Studies in Honour of Professor Kristian Kristiansen: 21-25, Oxford: Oxbow (British Archaeological Reports 2508).

R. B. (2013). Barcelona atrau milers de visitants a la tardor gràcies als congressos i convencions. 20 minutos, 9-9-2013: <https://www.20minutos.es/noticia/1912835/0/ barcelona/turisme/congressos/>.

24. <https://www.e-a-a.org/EAA/Navigation_News/2018_AMBM. aspx $>$.

$25<$ https://beteve.cat/terricoles/margarita-diaz-Andreu/>. 